\title{
Adaptive Finite Element Method for Shape Modification in Optimization of Electric Machines
}

\author{
Katsumi Yamazaki Member (Chiba Institute of Technology) \\ Hiroki Ishigami Student Member (Chiba Institute of Technology)
}

Keywords: adaptive finite element method, optimization, Rosenblock's method, IPM motor, iron loss

In this paper, we propose a modification method of finite element meshes based on the adaptive meshing for optimization algorithms of electric machines. Figure 1 shows the outline of the method. The mesh for the new shape of the machine in the optimization process is generated from the mesh of the previous shape with minor modification. The locations of the nodes for the new shape are decided by solving the Laplace's equation, whose unknowns are displacements of the nodes. The adaptive finite element meshing is started from the modified mesh. As a result, the iteration of the adaptive finite element meshing is reduced because the difference between the electromagnetic field distributions of the new and previous shape is slight in the cases of the minor shape modifications. Furthermore, the method can reduce the influence of the mesh variation in the estimation of the machine characteristics.

The proposed method is applied to the shape optimization of an interior permanent magnet motor to reduce the harmonic iron losses. Figure 2 shows the design variables. The Rosenblock's method is applied to the optimization algorithm. Figure 3 shows the variation of the objective function, which is expressed as

$$
W=\sum\left(k B_{k}\right)^{2}
$$

where $B_{k}$ is the space harmonic component of the air-gap flux density and $k$ is the harmonic order. Equation (1) is nearly corresponding to the harmonic iron losses. For the comparison, the same optimization algorithm is carried out with the conventional adaptive finite element method. It indicates that the proposed method can obtain the better results with small number of optimizing iteration. In addition, the average number of the adaptive mesh iteration is reduced nearly as $1 / 6$. As a result, the total calculation time for the optimization is reduced nearly as $1 / 7$. The advantages of the proposed method are verified.

The motor, whose design is obtained by this calculation, is manufactured and tested to examine the validity. It is clarified that the iron loss is reduced as half compared with the original motor.

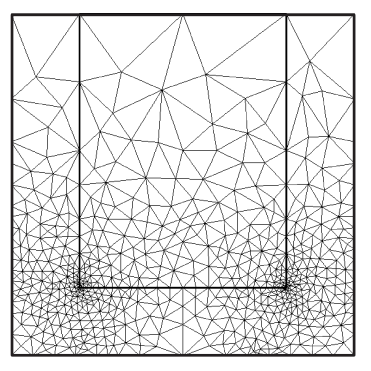

Previous Mesh

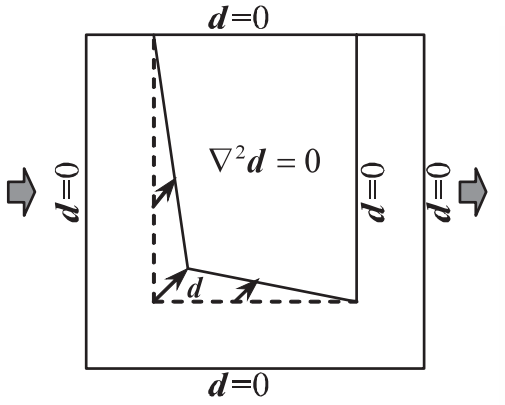

Shape modification

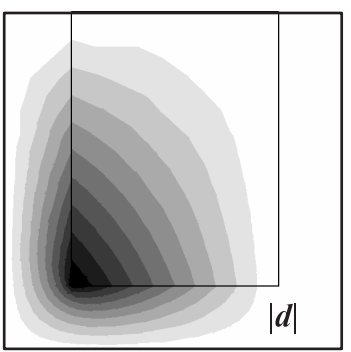

Solve Laplace's Equation of $\boldsymbol{d}$

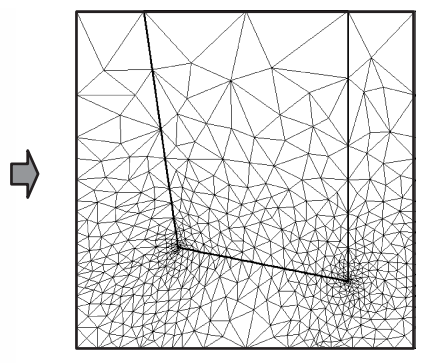

Modified Mesh

Fig. 1. Process of optimizing rotor shape

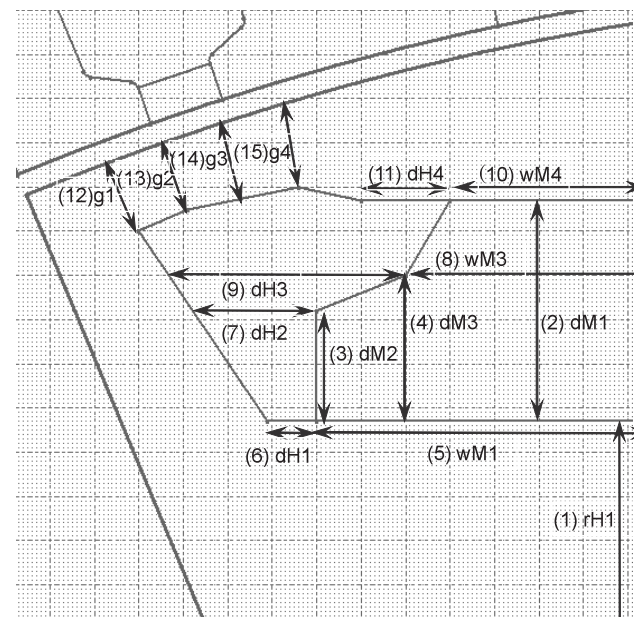

Fig. 2. Design variables of IPM motor

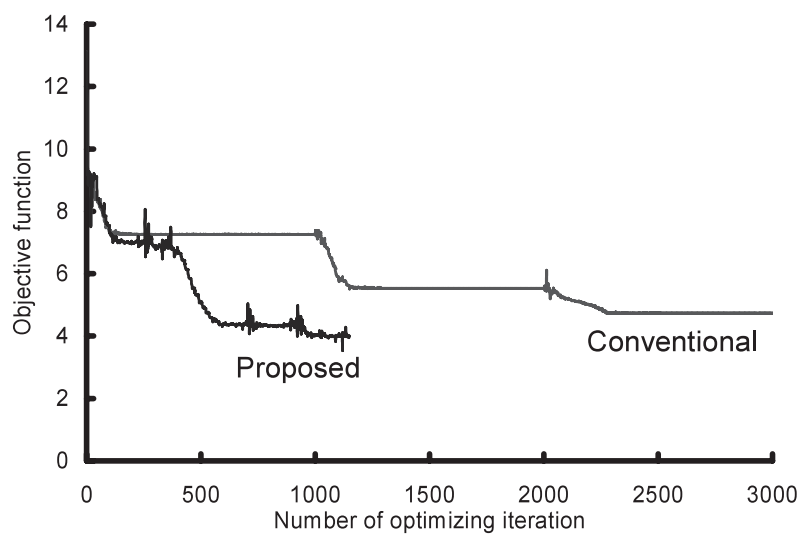

Fig. 3. Variation of objective function in optimization process 


\title{
電気機器の最適化計算のための形状修正アダプティブ有限要素法
}

\author{
正 員 山崎 克巳* 学生員 石上 洋希*
}

\section{Adaptive Finite Element Method for Shape Modification in Optimization of Electric Machines}

Katsumi Yamazaki*, Member, Hiroki Ishigami*, Student Member

\begin{abstract}
A modification method of finite element meshes based on the adaptive meshing for optimization of electric machines is proposed. In the optimization process of the machine, the proposed method generates the mesh for the new shape from the previous mesh with minor modification. The locations of the nodes for the new shape are decided by solving the Laplace's equation, whose unknowns are displacements of the nodes. The advantages are clarified by the application to the shape optimization of an IPM motor.
\end{abstract}

キーワード : アダプティブ有限要素法, 最適化計算, ローゼンブロック法, IPM モータ, 鉄損

Keywords: adaptive finite element method, optimization, Rosenblock's method, IPM motor, iron loss

\section{1. まえがき}

本論文は，電気機器における形状最適計算を高速かつ確 実に行うための，アダプティブメッシュ法に基づく自動有 限要素生成法について提案・検討するものである。

近年, 有限要素法による電磁界解析は, 電気機器の設計 · 開発において不可欠なツールとなっており，所望の特性が 得られるような機器の形状を探索するため, 細部の形状を 繰り返し変更する検討や, 自動最適化計算が盛んに行われ るようになっている(1)。この場合，形状を変更するたびに メッシュの一部を再度分割する必要があり，多くの作業時 間を要することが多い。また，形状の変化による特性変化 を正確に評価するには，メッシュの変化が特性算定結果に 影響を及ぼさないよう，メッシュを十分細かくしたり，要 素形状が扁平にならないようにするなどの，メッシュ分割 における配慮を行う必要があるといえる。

一方, 機器の形状に応じて, 適切な要素分割を自動的に 得る方法として, 疎分割の初期メッシュから, 解の誤差評 価に従って，デローニ法などによる自動要素分割と電磁界 解析を自動的に繰り返し行い, 最終的なメッシュを決定す る，アダプティブ有限要素法が開発されている(2)(3)，また本 手法を回転機などの電気機器へ適用することも行われつつ ある (4)。しかし本方法を用いて, 多数の形状変更に伴う繰

\footnotetext{
千葉工業大学 工学部 電気電子情報工学科

干 275-0016 習志野市津田沼 2-17-1

Dept. of Electrical, Electronics and Computer Engineering, Chiba Institute of Technology

2-17-1, Tsudanuma, Narashino 275-0016
}

り返し計算を行うと，次の二つの問題が生じる場合がある と考えられる。第一に, 形状変更の反復毎にアダプティブ メッシュ法の反復を行うことになるため, 計算時間が膨大 となる恐れがある。第二に, 形状によって最終的な要素分 割が大幅に異なる場合があり，メッシュ変化と形状変化が 計算結果に及ぼす影響を分離することが難しくなる恐れが ある。この二つの問題の両方を解決する手法は, 筆者の知 る限り未だ開発されていない。

このような背景から本論文で提案するのが, 形状変更に 伴って, 有限要素の節点を必要最小限移動させ, 形状変更 後におけるアダプティブ有限要素法解析の初期メッシュと して用いる方法である。図 1 に提案手法の処理過程の概略 を示す。まず，変更する前の形状におけるアダプティブ有 限要素法解析よって得られたメッシュを用い, 形状変更に 伴う節点の移動量を未知数とするラプラス方程式を解く。 その際, 輪郭線の移動量を境界条件として与える。次に得 られた各節点の移動量に従ってメッシュを修正する。これ を初期メッシュとして, 形状修正後のアダプティブ有限要 素法解析を開始する。

このような方法を取ることにより，メッシュを変更する 領域を必要最小限とし，なおかつ形状修正前のメッシュの 粗密を極力生かしつつ, 形状修正後の電磁界解析を行うこ とができる。その結果，アダプティブメッシュの反復回数 を低減でき, 更にメッシュ変更が特性解析結果に及ぼす影 響の低減も期待できる。また, 節点移動量の解析は線形解 析であり, 解析領域も形状が変化した周辺のみであるため, 計算時間は電磁界解析と比較して非常に短く, 無視できる 程度である。以後, 本手法を形状修正アダプティブ有限要 


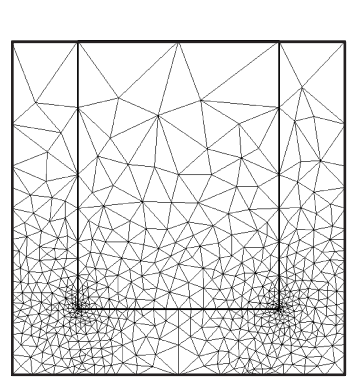

Previous Mesh

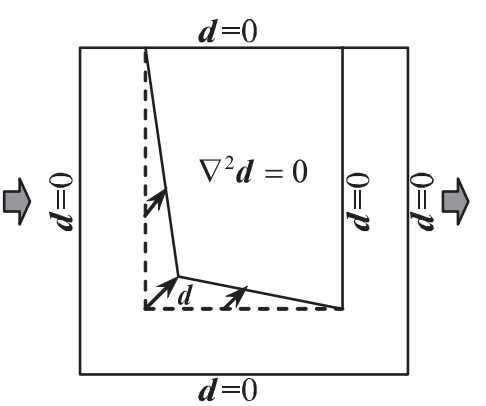

Shape modification

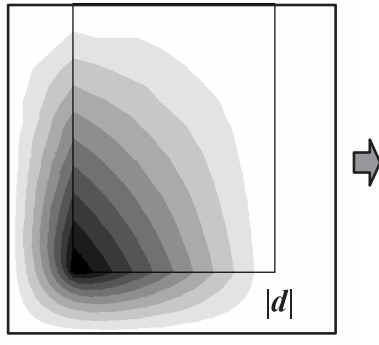

Solve Laplace's Equation of $\boldsymbol{d}$

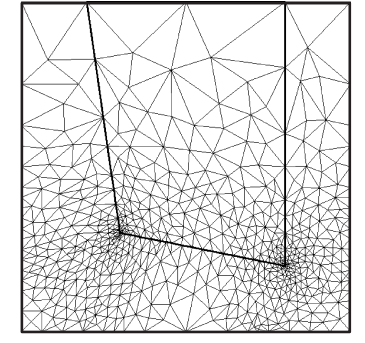

Modified Mesh

図 1 提案手法の処理過程

Fig. 1. Procedure of proposed method.

素法と呼ぶ。

本論文では，提案手法を IPM モータの高調波鉄損低減を 目的とした形状最適化計算に適用し，手法の有用性を確認 する。また，得られた結果に基づいて実機を試作 (7)し，効 果を確認した結果について示す。

\section{2. 計算手法}

$\langle\mathbf{2} \cdot \mathbf{1}\rangle$ 計算の前提条件 本論文では, 二次元定常静 磁界解析を前提として検討を行うこととする。支配方程式 は次式で与えられる。

$$
-\nabla \cdot\left(v \nabla A_{z}\right)=J_{z}+v_{0}\left(\frac{\partial M_{y}}{\partial x}-\frac{\partial M_{x}}{\partial y}\right)
$$

ここで, $A_{z}, J_{z}$ はそれぞれ, 磁気べクトルポテンシャルと 励磁電流の $z$ 成分, $v$ は磁気抵抗率, $v_{0}$ は真空の磁気抵抗 率, $M_{x}, M_{y}$ は磁石の磁化の $x, y$ 成分である。

また，使用要素は三角形一次要素とする。この場合，要 素内で磁束密度 $\boldsymbol{B}$ は一定值となる。

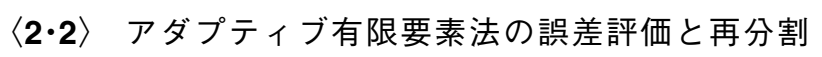
本論文では，メッシュを自動再分割する際の有限要素 の䛊差評価にZienkiewicz と Zhu の方法 ${ }^{(3)}$ を用いることと する。本方法に扔ける要素 $e$ の推定誤差 $\xi_{\text {error }}{ }^{e}$ は, 有限要 素法解析で得られた各要素の磁束密度 $B^{e}$ および推定真值 $B_{\text {true }} e^{e}$ より求妨られ。二次元解析の場合は次式で与えら れる。

$$
\xi_{\text {error }}{ }^{e}=\frac{E_{\text {error }}{ }^{e}}{E_{\text {ave }}} \times 100(\%)
$$

ここで,

$$
\begin{array}{r}
\left(E_{\text {error }}^{e}\right)^{2}=\frac{1}{2} \int_{S e}\left(\boldsymbol{B}^{e}-\boldsymbol{B}_{\text {true }}{ }^{e}\right) \cdot v^{e}\left(\boldsymbol{B}^{e}-\boldsymbol{B}_{\text {true }}{ }^{e}\right) d S \\
\ldots \ldots \ldots \ldots \ldots \ldots \\
\left(E_{\text {ave }}\right)^{2}=\frac{1}{2 N E} \sum_{e=1}^{N E} \int_{S e} \boldsymbol{B}^{e} \cdot v^{e} \boldsymbol{B}^{e} d S \ldots \ldots \ldots \ldots
\end{array}
$$

であり, $B_{\text {true }}{ }^{e}$ は周辺の要素の平均值より求める(4)。なお, $v^{e}, S_{e}$ はそれぞれ要素 $e$ の磁気抵抗率と面積, $N E$ は要素 数である。

メッシュを再分割する際の閾値である許容誤差係数 $\eta^{(4)}$
を予め設定しておき, $\xi_{\text {error }}{ }^{e}$ が $\eta$ より大きい要素を検出して 再分割した後, 有限要素法解析を反復して行う。全ての要 素の $\xi_{\text {error }}{ }^{e}$ が $\eta$ より小さくなったところで反復を終了する。

$\langle\mathbf{2} \cdot \mathbf{3}\rangle$ 形状変化に伴う節点移動アダプティブ有限 要素法によって一つの形状に対する電磁界解析が終了した 後, 最適化手法によって変更した形状に従ってメッシュを 修正する。具体的には, 各節点に打ける座標の修正べクト ルを $\boldsymbol{d}$ とし, 次の手順に従って求める。

（i）形状変更に伴って変化した輪郭線を検出する。

(ii) 座標修正べクトル $\boldsymbol{d}$ を決定するためのラプラス方 程式を解く領域は, 変化した輪郭線を含む領域のみとし, 修 正前のメッシュにおいて，これ以外の領域に位置する節点 の $\boldsymbol{d}$ は零に固定する。

(iii) 修正前のメッシュにおける輪郭線上の節点に, 輪郭 線の変更に対応する移動べクトル $\boldsymbol{d}$ を固定境界条件として 与える。

(iv) 以上の設定に従って, 次のラプラス方程式の解を有 限要素法によって求める。

$\nabla^{2} \boldsymbol{d}=0$

その際のメッシュは, 形状修正前の電磁界解析用メッシュ を用いることができる。また，上記の方程式の解は， $\boldsymbol{d}$ の 各方向成分毎に求めることができる。

(v) (5) 式の解に従って, 各節点の座標 $\boldsymbol{x}_{i}$ を次のように $\boldsymbol{x}_{i}{ }^{\prime}$ に修正する。

$$
\boldsymbol{x}_{i}^{\prime}=\boldsymbol{x}_{i}+\boldsymbol{d}
$$

〈2・4 要素形状安定化のための処理 前述の手順の みにしたがってメッシュを修正すると，形状修正前のメッ シュの粗密を生かせる反面, 座標修正べクトル $\boldsymbol{d}$ が局所的 に極端に大きいような場合, 要素がつぶれる恐れがある。そ こで, 次のような要素分割安定化のための処理を追加する。

(vi）つぶれた要素を次式に従って検出する。

$$
\begin{aligned}
& \left\{\left(\boldsymbol{x}_{3 e}+\boldsymbol{d}_{3 e}\right)-\left(\boldsymbol{x}_{2 e}+\boldsymbol{d}_{2 e}\right)\right\} \\
& \quad \times\left\{\left(\boldsymbol{x}_{1 e}+\boldsymbol{d}_{1 e}\right)-\left(\boldsymbol{x}_{2 e}+\boldsymbol{d}_{2 e}\right)\right\} \leq 0
\end{aligned}
$$

ここで図 2 に示すように, $\boldsymbol{x}_{1 e} \sim \boldsymbol{x}_{3 e}$ と $\boldsymbol{d}_{1 e} \sim \boldsymbol{d}_{3 e}$ はそれぞれ， 


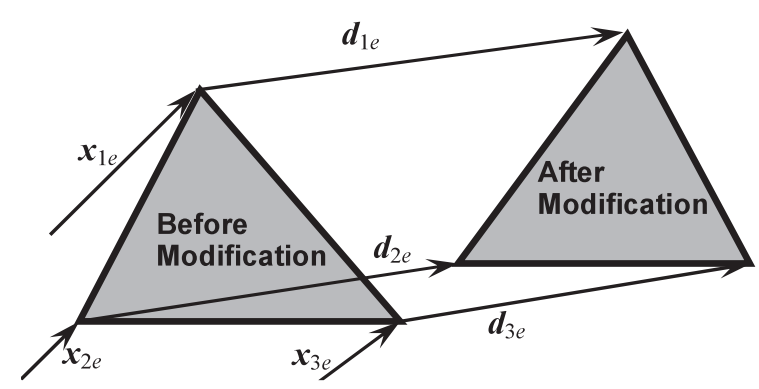

図 2 節点の移動に伴う要素形状

Fig. 2. Shape of element due to node displacement.

要素 $e$ における各節点の位置ベクトルと, 座標修正べクト ルである。要素がつぶれて面積が 0 となっている場合，(7) 式左辺は零となり, 更に裏返った場合はマイナスとなる。

(vii) つぶれた要素 $e$ がある場合は，これに含まれる各 節点の座標修正べクトル $\boldsymbol{d}_{i e}$ を，次式に従って調整する。

$$
\boldsymbol{d}_{i e}{ }^{\prime}=\alpha \boldsymbol{d}_{e M a x}+(1-\alpha) \boldsymbol{d}_{i e}
$$

ここで $\boldsymbol{d}_{e M a x}$ は要素 $e$ に含まれる各節点の座標修正べクト ルの最大值， $\alpha$ は修正量調整係数である。 $\alpha=0$ とすると, $\boldsymbol{d}_{i e}{ }^{\prime}$ は (5) 式によって求められた座標修正べクトルと同一 となり, 要素 $e$ のつぶれは回避できない。一方, $\alpha=1$ と すると要素 $e$ 全体が平行移動することとなり, 要素 $e$ のつ ぶれは確実に回避できるが, 今度は要素 $e$ 周辺の要素の形 状に悪影響を及ぼす恐れがある。そこでここでは，(8) 式を (7) 式に代入して, 左辺が 0 となる（要素面積が 0 となる） $\alpha$ である $\alpha_{0}$ を求め, 次式に従って $\alpha$ を決定した。

$$
\alpha=(1-\lambda) \alpha_{0}+\lambda
$$

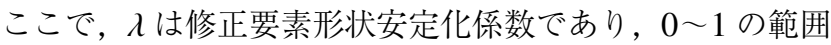
で設定する。 $\lambda$ を 0 に近い值に取ると，修正した要素形状 の面積が 0 に近くなり，不適切といえる。一方， 1 に近い 值にとると，要素を平行移動する場合に近くなる。本論文 では一つの設定法として， $\lambda=0.5$ に固定した。

（viii）（8）式に従って調整した節点座標は固定し，(iv)〜 （vii）の手順を繰り返す。すなわち，まず境界上の節点に加 え，(8) 式に従って座標修正べクトルを調整した節点のdを 既知として，再度 (5) 式のラプラス方程式を解き，節点座 標を修正する。その際, 新たに他の要素のつぶれが発生し た場合は，その要素に含まれる節点に関して座標修正べク トルを調整する。この場合，調整する度に移動可能な節点 数が減少してゆく。

(ix) 座標を修正できる節点が無くなり，要素つぶれが回 避できなくなった場合は, 形状変更後の輪郭線より, 改め て初期メッシュを作成する。

以上の $(\mathrm{i}) \sim(\mathrm{ix})$ の処理に必要な計算時間は, 座標修正べ クトル $\boldsymbol{d}$ を求める範囲が限定されているため, 多くの場合 電磁界の方程式を解く場合と比較して, 無視できる程度に 小さい。

また，このようにして得られたメッシュは, 形状変更前
のアダプティブ有限要素法によって決定された要素の粗密 が極力残されているため，これを初期メッシュとして形状 修正後のアダプティブ有限要素法解析を行うと, 反復回数 と計算時間が大幅に短縮できる。

〈2.5〉最適化手法一リフレッシュ機能付ローゼンブロッ ク法本論文では最適化手法にローゼンブロック法 ${ }^{(5)}$ を 採用することとする。本手法は, 各設計変数を交互に少し ずつ変化させ, 最適な設計変数を探索する手法である。こ のため, 本手法における各ステップにおいては, 形状の変 化が比較的小さい場合が多く，形状修正アダプティブ有限 要素法の真価が発揮される最適化手法の一つであると考え られる。

ローゼンブロック法においては，各ステップの探索の成 功と失敗に応じて, 各設計变数の探索幅を次のように逐次 修正してゆく。

$$
\Delta L_{i j+1}=\gamma \Delta L_{i j}
$$

ここで $\Delta L_{i j}$ は $i$ 番目の設計変数の $j$ 回目の探索における 探索幅, $\gamma$ は探索幅変更係数であり, 探索に成功した場合 は 1 より大きくして, 次回の探索は大胆に行うこととし, 失敗した場合は 1 より小さくする。

上記の方法を繰り返し, 全ての設計変数の変化の組み合 わせで探索が失敗したところで最適化計算を終了する。な お，探索が進むにつれて，最適な設計変数が絞り达まれて くることから, 最適化計算の終盤では, 各設計变数の探索 幅が小さくなってゆく傾向がある。

本手法は，実用的な計算時間内で必ず何等かの結果が得 られる反面, 局所的な最適解に陥ることが多いという久点 がある。そこで本論文では, この欠点を改善するため, 一旦 最適化計算が終了したところで, 各設計変数の探索幅を次 のように初期值に戻し，改めて探索を開始することとした。

$$
\Delta L_{i j+1}=\Delta L_{i 0}
$$

このような方法を取ることにより，局所的最適解を乗り 越えて，実用的な計算時間内で更に最適な設計変数の組み 合わせを得ることができると考えられる。探索幅を逐次変 更して局所解を回避する方法として, Simulated Annealing 法 ${ }^{(5)}$ が知られているが，本論文で用いる手法は，探索幅変 更を最適化が終了した時点に限定する点で異なる。以後, 本手法をリフレッシュ機能付ローゼンブロック法と呼ぶ。

\section{3. 適用例}

$\langle\mathbf{3} \cdot \mathbf{1}\rangle$ 対象機 ここでは最大出力 $100 \mathrm{~kW}$ の IPM モータに関して, 弱め界磁制御時の高調波鉄損低減を目的と した最適化計算に提案手法を適用する。表 1 に供試機の諸 元 ${ }^{(6)}$ を示す。本機は鉄損算定精度検証用に試作されたIPM モータであり, 固定子・回転子鉄心はワイヤーカット放電 加工で作製されている。回転子には一層のネオジム磁石が 埋め込まれており, 渦電流損を防ぐ目的で軸方向に 28 分割 されている。一方, 電源はキャリア周波数 $10 \mathrm{kHz}$ の IGBT 
表 1 供試機の諸元

Table 1. Specifications of motor.

\begin{tabular}{c|c}
\hline Phases and poles & 3 phases, 8 poles \\
\hline DC voltage $[\mathrm{V}]$ & 400 \\
\hline Carrier frequency $[\mathrm{kHz}]$ & 10 \\
\hline Maximum rotational speed $\left[\mathrm{min}^{-1}\right]$ & 10,000 \\
\hline Maximum output $[\mathrm{kW}]$ & 100 \\
\hline Diameter of stator and core length $[\mathrm{mm}]$ & 180,130 \\
\hline Number of stator slot & 48 \\
\hline Magnet & $\mathrm{Nd}-\mathrm{Fe}-\mathrm{B}$ \\
\hline Thickness of steel plate for core $[\mathrm{mm}]$ & 0.2 \\
\hline
\end{tabular}

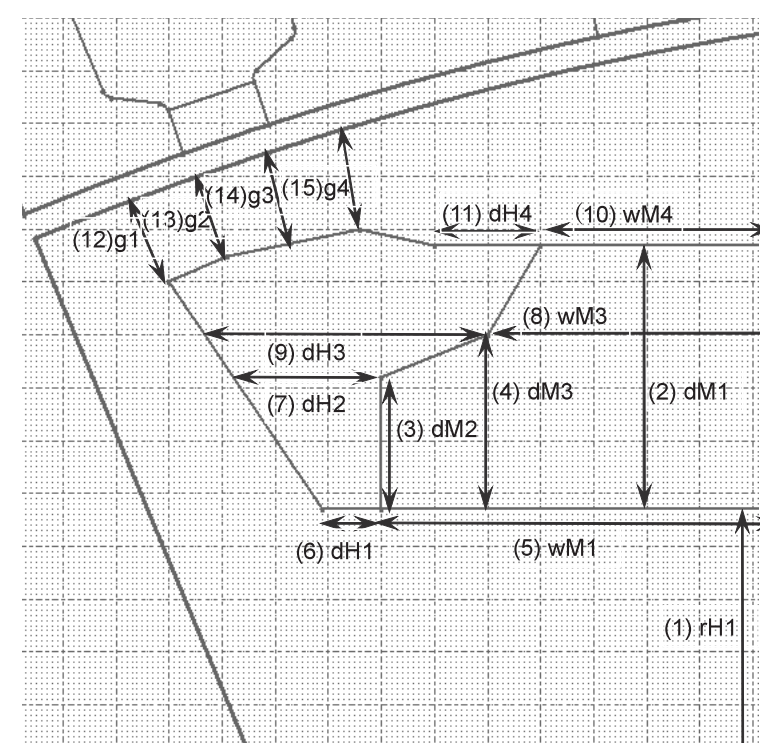

困 3 設計変数

Fig. 3. Design variables.

\section{インバータである。}

弱め界磁制御時の高調波鉄損は, 主として回転子起磁力高 調波に起因することから ${ }^{(6)}$ ，ここでは設計変数として，図 3 に示す回転子鉄心および永久磁石における 15 箇所の寸法 を取り，鉄損を低減する形状を探索することとした。

$\langle\mathbf{3} \cdot 2\rangle$ 鉄損評価関数の導入とトルクの制約条件高 調波を含む回転機の鉄損を算出するには，回転運動を考慮 したタイムステップの非線形非定常有限要素法解析が必要 である。一方，自動最適化計算においては，この解析を場 合によっては数千回繰り返す必要があり，膨大な計算時間 が必要となる ${ }^{(6)}$ 。

そこでここでは, 最適化計算における目的関数として, 直 接鉄損を用いるのでなく，ギャップ磁束密度の高調波成分 から表される次式の $W$ を導入し，これを最小化する形状を 探索することとする (7)。

$$
W=\sum\left(k B_{k}\right)^{2}
$$

ここで, $k$ : ギャップ磁束密度波形の空間高調波次数, $B_{k}$ : 第 $k$ 次空間高調波磁束密度。

(12) 式を導入した根拠は, 弱め界磁制御時の鉄損の主要 因が鉄心および磁石の形状に依存する回転子の起磁力高調
波であることと ${ }^{(6)}$ ，この高調波鉄損の主成分は渦電流損で あり，周波数と磁束密度の 2 乗に比例すると考えることが できるためである。(12) 式の $W$ は定常静磁界解析で求め ることが可能であり，実用上許される計算時間で最適化計 算を行うことが期待できる。ここでは，電流位相角が進ん で波形が大きく歪む代表的な駆動条件として，電機子電流 $I_{a}=600 \mathrm{~A}$ ，電流位相角 $\beta=80 \mathrm{deg}{ }^{\left({ }^{(6)}\right.}$ における $3,5,7,9$ 次高調波を考慮することとする。

ギャップ磁束密度を求めるためのアダプティブ有限要素 法における許容誤差係数 $\eta$ は $10 \%$ とした。また，ローゼン ブロック法による最適化計算の過程において, 瞬時トルク が初期形状より減少した場合は探索失敗とみなすことによ り，トルクが初期形状より落ちない制約条件を与えた。

$\langle\mathbf{3} \cdot \mathbf{3}\rangle$ 形状最適化の過程図 4 に最適化計算の反復 に対する目的関数 $W$ の変化を示す。比較の目的で, 従来手 法として, 形状および輪郭データが変更される度に, 疎分 割の初期メッシュからアダプティブ有限要素法解析を開始 した結果も同時に示す。なおローゼンブロック法における 探索幅の初期值は各設計変数の可動範囲の $1 / 50$, 探索幅変 更係数は成功時 1.2 , 失敗時 0.5 , 探索回数の上限は 1000 回 とした。これらは, 各種電気機器の最適化を通して, 経験 的にプログラムが効率的に動作する值として設定している。 また最適化の反復計算終了後における探索幅のリフレッ シュは, 探索に成功する限り繰り返し行った。結果として リフレッシュは 2 回行われ, 局所的最適解を乗り越えて, より適切な設計変数の組み合わせを見つけ出すことに成功 していることがわかる。この点に関しては提案手法も従来 手法も同様である。一方, 提案手法と従来手法を比較する と, 提案手法はより適切な形状を, より少ない反復回数で 探し当てていることがわかる。これは前述のように，提案 手法においては形状変更に対するメッシュの変更を極力少 なくしているため, メッシュの違いによる計算精度の変化 が少なく, 形状の違いによる特性変化のみを抽出して正確 に評価できているためと考えられる。これに対して従来手 法の場合は, 特に設計変数の変化が非常に小さくなる最適 化計算の終盤において，形状变化に対する目的関数の評価 が不安定となるため, 本来は探索失敗であるところを成功 と見誤ることが多くなる。その結果, 探索を終了すること が困難になっている。

図 5 に，このときの提案手法と従来手法におけるアダプ ティブ有限要素法の反復回数の変化を示す。従来手法の場 合は, 形状が変更される度に, 新しい輪郭線に従って疎分割 の初期メッシュを新たに生成してアダプティブ有限要素法 の反復を開始するため, 各形状において概ね 10〜12 ステッ プのメッシュ変更が行われている。これ対して, 提案手法 においては, 多くの場合 1〜4 ステップ程度に削減できてい ることがわかる。ここでアダプティブメッシュの反復回数 が 1 とは，〈2·2〉およびく2.3〉節で示した形状変化に伴う 節点移動と要素微修正を行っただけで, 全要素が許容誤差 係数を下回り, 再分割と再解析の反復が不要であったこと 


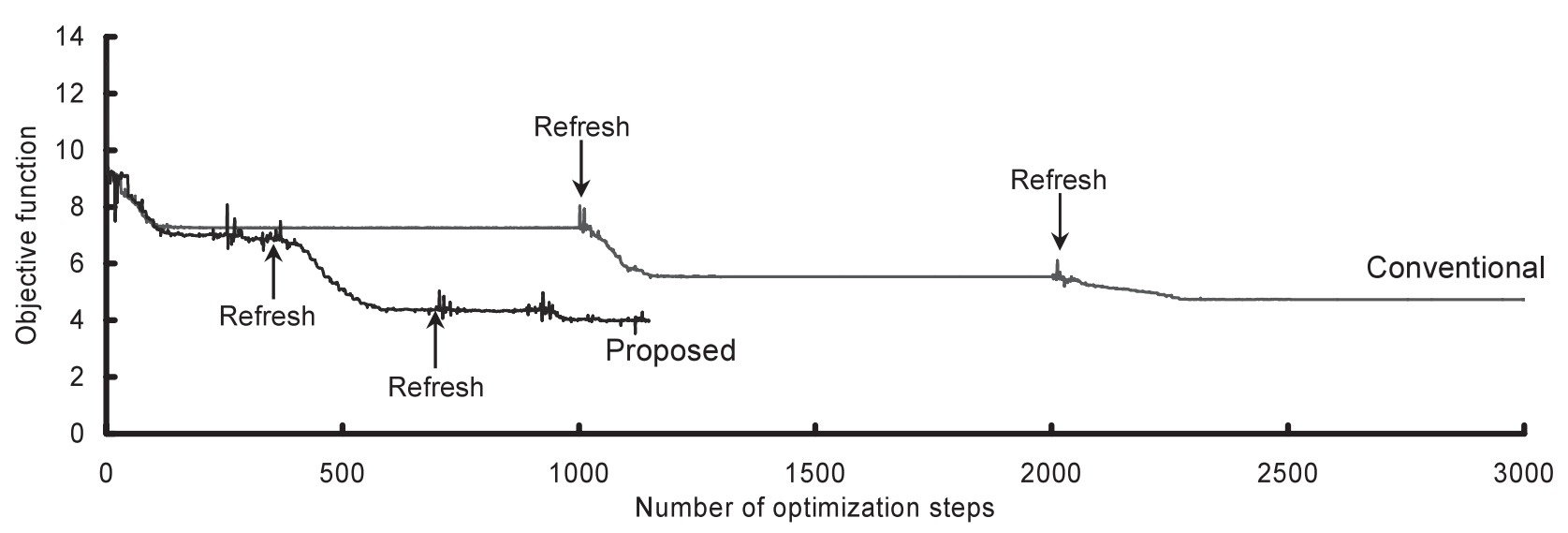

図 4 最適化計算の反復に対する目的関数の変化

Fig. 4. Variation of objective function due to iteration of optimization procedure.

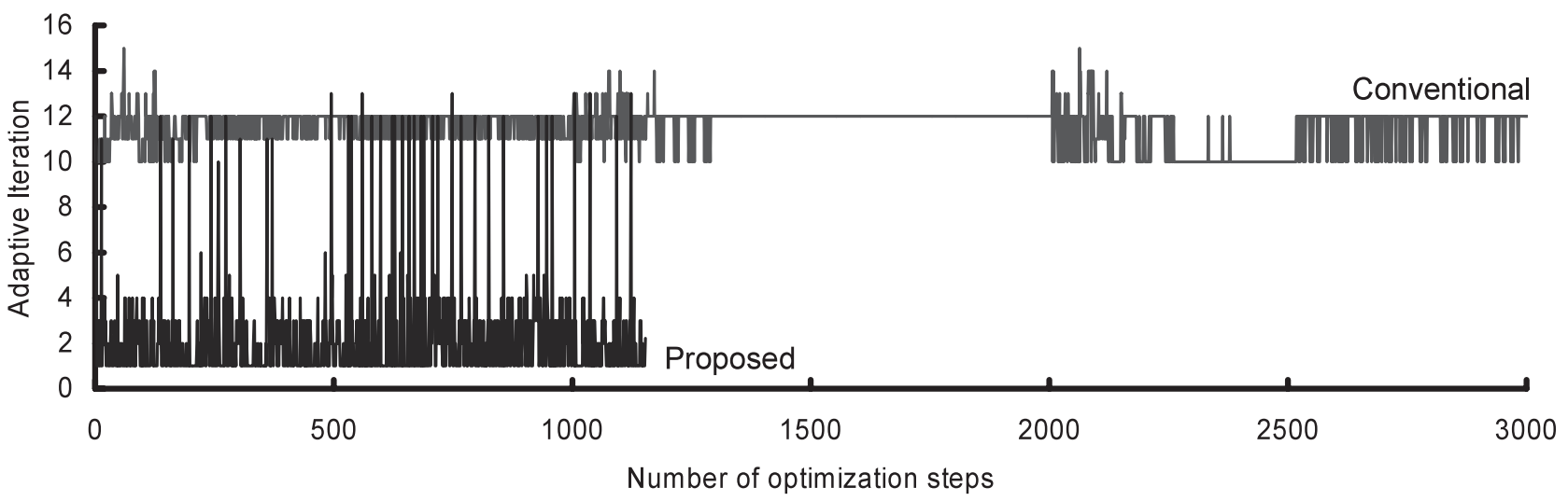

図 5 最適化計算の反復に対するアダプティブメッシュ法の反復回数

Fig. 5. Number of adaptive mesh iteration due to iteration of optimization procedure.

を表している。一方，一時的にアダプティブメッシュの反 復回数が 10 回以上となる場合があるが，これは，〈2·3〉節 で述べたように，座標修正べクトル $\boldsymbol{d}$ が局所的に極端に大 きく，要素つぶれが回避できずに初期メッシュから切りな おした場合に相当する。但しこのような例外処理が働くの は, 形状変更が数 10 回に 1 回程度となっている。

表 2 に最適化計算の諸元を示す。図 4, 図 5 に示したよ うに, 提案手法においては, 従来手法と比較して最適化計 算の反復回数が約 $1 / 3$ ，アダプティブ有限要素法の反復回 数が約 $1 / 6$ に削減された結果，最適化に要した総計算時間 は約 $1 / 7$ となり，1 形状あたりの計算時間でも約 $1 / 3$ となっ ている。結果として普及機クラスの PC を用いて，約 1 時 間で全ての計算が終了しており，実用的な時間で最適化計 算が行えている。

図 6 に最適化形状の探索過程と最終形状を示す。最適化 計算が進むにつれ，磁石のギャップ側の鉄心に穴が開いて ゆく。さらに穴の中央付近が凹み，最終的に (12) 式の目的 関数は約 $1 / 3$ となった。一方瞬時卜ルクに関しては，初期 形状以上となる制約条件を課しているため，大きな変化は ない。

なお，前述の最適計算によって得られた形状の遠心力解
表 2 最適化計算の諸元

Table 2. Specifications of optimization.

\begin{tabular}{c|c|c}
\hline Specifications & Conventional & Proposed \\
\hline Number of optimizing iterations & 3000 & 1146 \\
\hline Average number of adaptive iterations & 11.6 & 2.2 \\
\hline Total calculation time & $7 \mathrm{~h} 25 \mathrm{~m} 15 \mathrm{~s}$ & $1 \mathrm{~h} 5 \mathrm{~m} 52 \mathrm{~s}$ \\
\hline Calculation time / Optimization step & $8.91 \mathrm{~s}$ & $3.45 \mathrm{~s}$ \\
\hline
\end{tabular}

Computer used : Pentium4 (2.8GHz) PC

析を行った結果，鉄心の穴の先端で応力が集中して降伏応 力を上回る可能性があることが分かったため，応力緩和を 目的として，鉄心の穴を三角バリアとスリットに分離した 後，形状を微調整している(7)。

〈3・4〉 実機試作による検証図 6 の最終形状のモー夕 を実際に試作し, 鉄損低減の効果を確かめる。また，キャリ ア高調波を考慮した三次元非線形非定常有限要素法解析 ${ }^{(6)}$ を行い, 結果を比較する。なお解析においては, キャリア 高調波の影響を精度良く考慮するために，時間刻みを電源 1 周期あたり 1024 ステップとした ${ }^{(6)}$ 。一方，実験における 鉄損は, 入力から出力, 銅損, 機械損を差し引くことによっ て求めた ${ }^{(6)}$ 。 


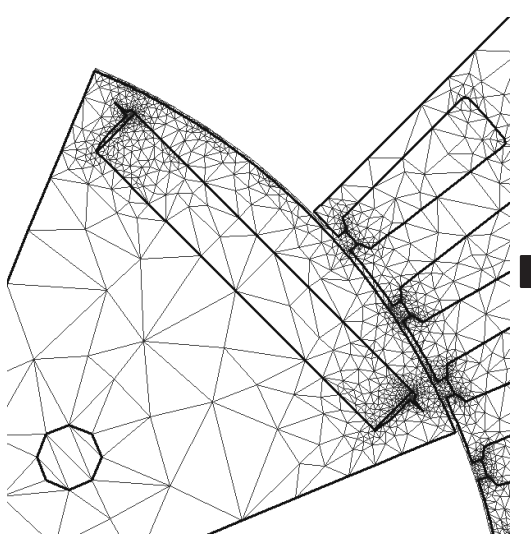

Original Shape $(W=13.1, \tau=59 \mathrm{Nm})$

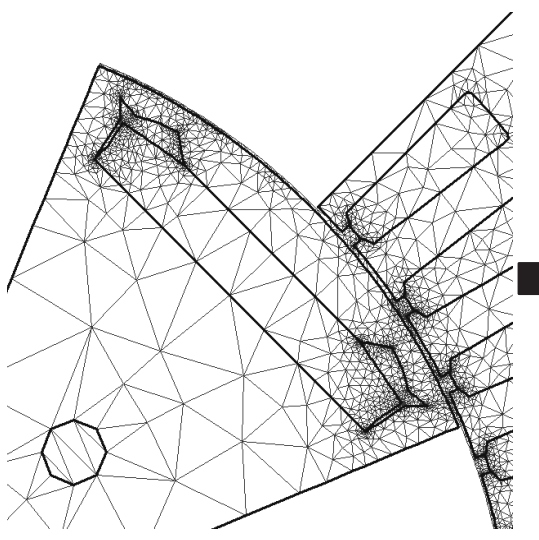

$(W=5.5, \tau=59 \mathrm{Nm})$

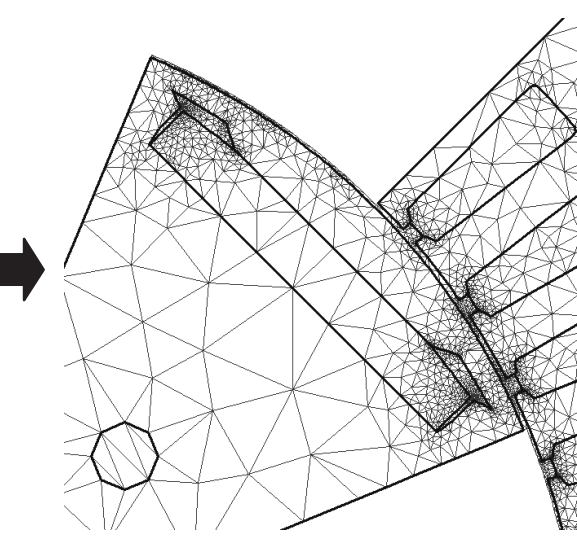

$(W=8.4, \tau=61 \mathrm{Nm})$

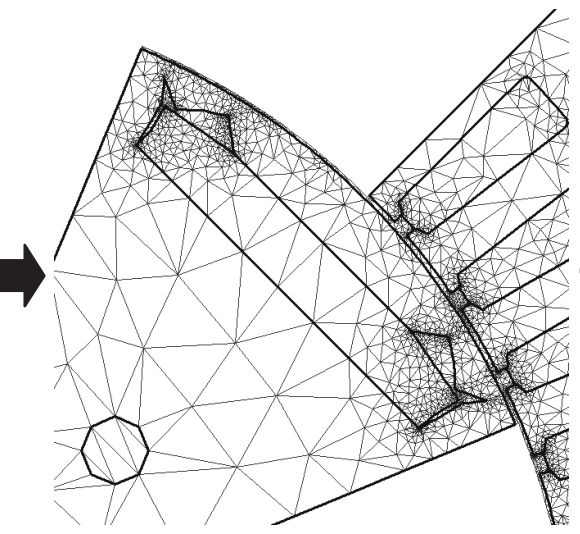

Optimized shape $(W=4.0, \tau=59 \mathrm{Nm})$

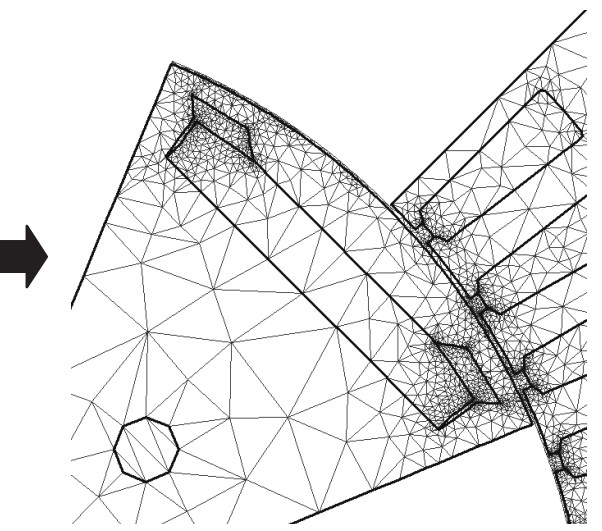

$(W=6.9, \tau=59 \mathrm{Nm})$

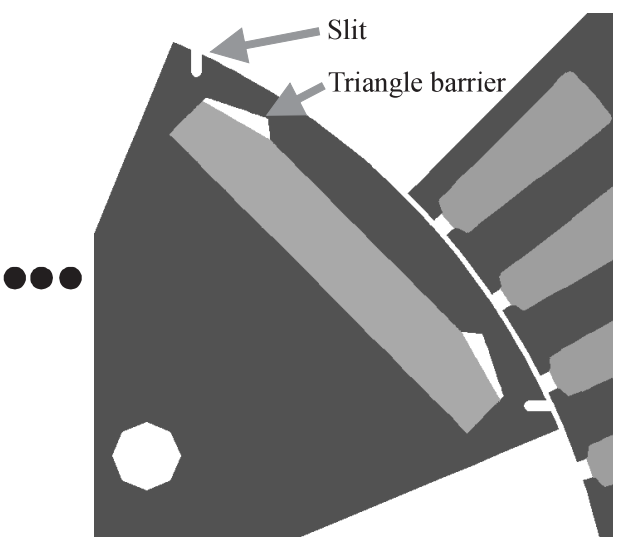

Final optimized shape $(W=3.6, \tau=59 \mathrm{Nm})$

図 6 最適化形状の探索過程と鉄心の応力集中を緩和した最終形状（ $\tau$ は瞬時トルク）

Fig. 6. Shape optimization process and final shape considering the stress decrease of core ( $\tau$ is instantaneous torque).

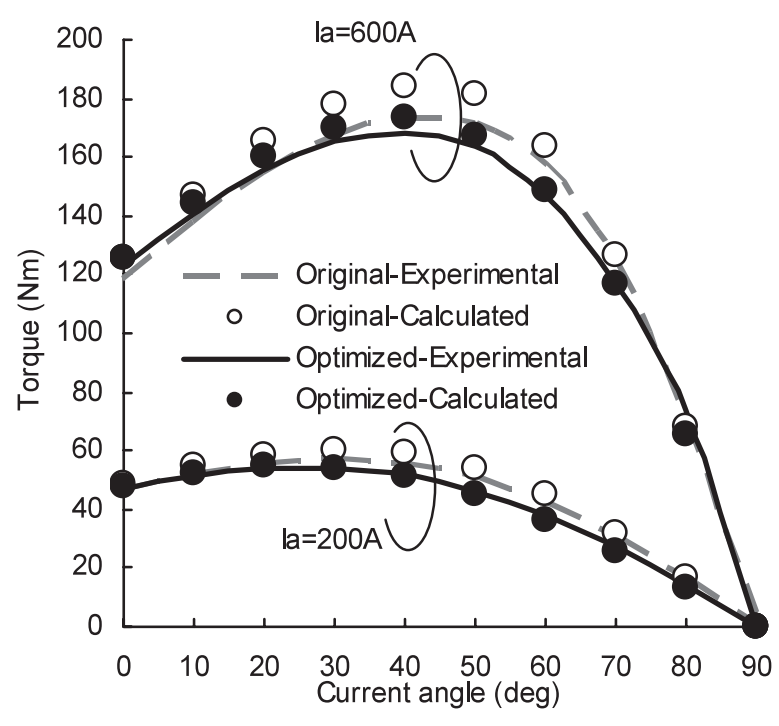

図 7 トルク特性の実験・解析結果

Fig. 7. Measured and calculated torque characteristics.

図 7 にトルク特性の実験・解析結果を示す。実験・解析 結果は良く一致している。また，初期形状と最適化形状を 比較すると, ピークトルクが $5 \%$ 程度減少しているものの, 大きな変化は無いことがわかる。

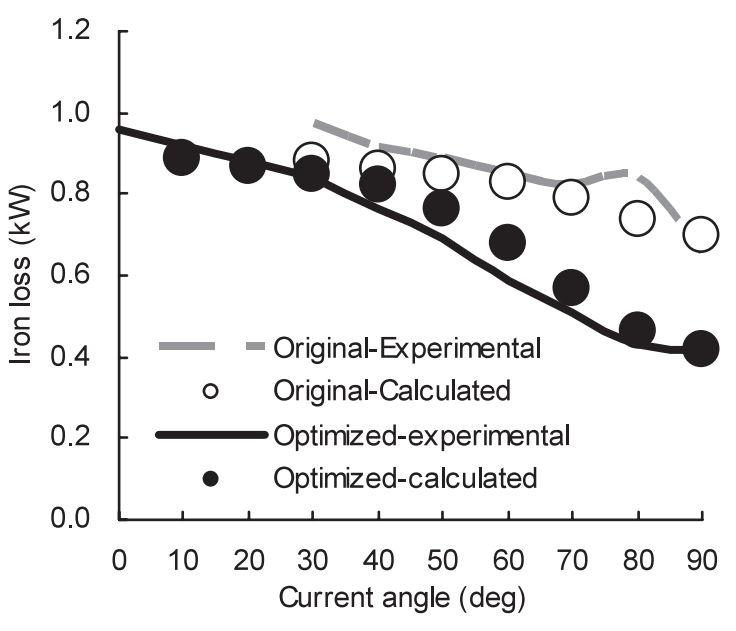

図 8 鉄損特性の実験・解析結果 $\left(I_{a}=200 \mathrm{~A}\right.$, $8000 \mathrm{~min}^{-1}$ )

Fig. 8. Measured and calculated iron loss characteristics.

一方, 図 8 に電機子電流 $I_{a}=200 \mathrm{~A}, 8000 \mathrm{~min}^{-1}$ におけ る鉄損特性の実験・解析結果を示す。実験・解析結果はや はり良く一致している。また弱め界磁制御時の鉄損は最大 $50 \%$ 程度低減しており, 形状最適化計算の妥当性が確かめ られた。 

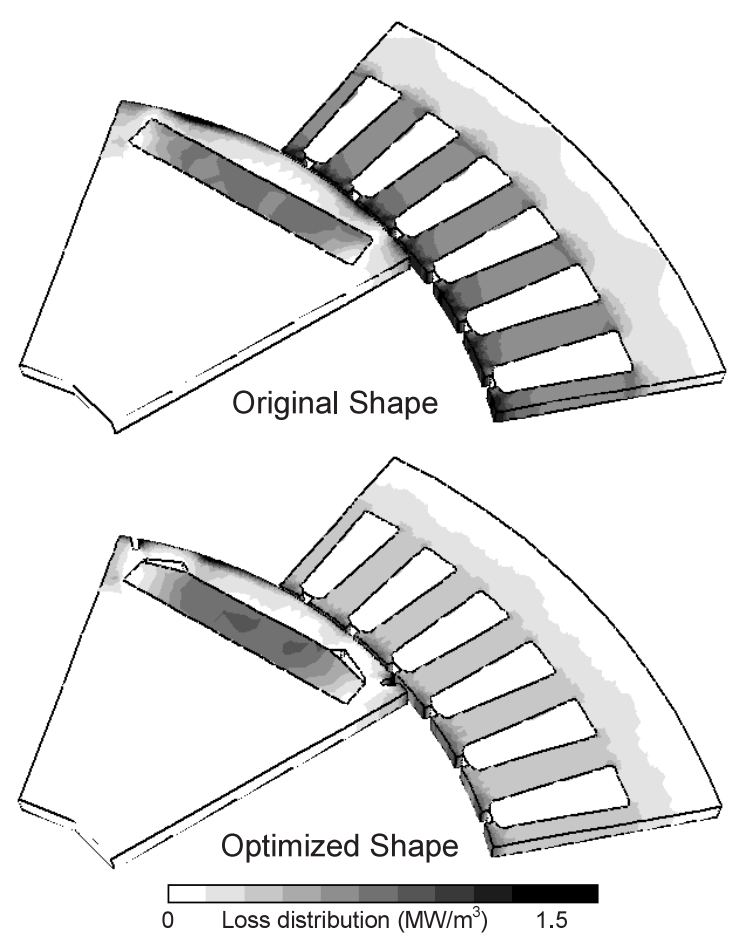

図 9 損失分布 $\left(I_{a}=200 \mathrm{~A}, \beta=80 \mathrm{deg}\right.$, $\left.8000 \mathrm{~min}^{-1}\right)$

Fig. 9. Loss distribution.

図 9 に損失密度分布を示す。最適化形状においては，回 転子起磁力高調波の減少により, 固定子鉄心の損失密度が 大幅に下がっていることがわかる。

\section{4. まとめ}

電気機器における形状最適計算を高速かつ確実に行うこ とを目的とした手法である, 形状修正アダプティブ有限要 素法を提案・検討した。本手法は，ローゼンブロック法な どのように形状を逐次微小に変化させる手法と組み合わせ ると，計算時間短縮と評価精度向上の両方に大きく寄与す ることが分かった。これは，最適化計算における 1 ステッ プ前の形状に従うメッシュを必要最小限修正して, 次の形 状のアダプティブ有限要素法解析に用いることで, アダプ ティブ有限要素法における反復回数を大幅に低減できると 同時に,メッシュの違いによる計算精度の違いが極力小さ くなっていることから，形状変化による特性変化をより正 確に捉えることができるためである。提案手法を IPM モー 夕に扔ける高調波鉄損低減を目的とした形状最適化計算に 適用し，上記の利点を確認することができた。また，得ら れた形状に基づいて実機を試作 (7)して評価した結果，弱め 界磁制御時の鉄損を半減させる効果があることが確かめら れた。

本論文では, 三角形一次要素による定常静磁界解析を前 提とした検討を行ったが，今後は提案手法を三角形一次要
素以外の有限要素, 渦電流解析及び三次元解析に適用でき るよう，拡張する予定である。また，提案手法を更に多く の事例に適用し, 妥当性と有効性について実績を積み上げ てゆく所存である。

最後にモー夕試作実験にご協力戴いた，日産自動車株式 会社，大木俊治氏，根津章氏，池見健氏に深謝致します。

な押, 本論文は平成 18 年度静止器・回転機合同研究会資

料 SA-06-93，RM06-95 を加筆訂正したものである。

(平成 18 年 10 月 12 日受付，平成 19 年 5 月 9 日再受付)

\section{文献}

（1）「回転機の電磁界解析高度化技術」, 電気学会技術報告, No.942 (2004)

(2) Z.J. Cendes and D.N. Shenton: "Adaptive mesh refinement in the finite element computation of magnetic field", IEEE, Trans. Magnetics, Vol.21, No.5, pp.1811-1816 (1985)

(3) O.C Zienkiewicz and J.Z. Zhu: "A simple error estimator and adaptive procedure for practical engineering analysis", Int. J. Numerical Method in Engineerings, Vol.24, pp.337-357 (1987)

(4) K. Yamazaki, S. Watari, T. Saeki, and Y. Sugiura: "Adaptive finite element meshing at each iterative calculation for electromagnetic field analysis of rotating machines", IEEJ Trans. IA, Vol.125, No.3, pp.259-269 (2005-3) (in Japanese)

山崎克巳 - 渡伸次郎 - 佐伯聡大 ・ 杉浦義典 :「回転機の電磁界解析 のための逐次アダプテイブ有限要素法」, 電学論 D, 125, 3, pp.259-269 (2005-3)

（5）高橋則雄：磁界系有限要素法を用いた最適化, 森北出版 (2001)

(6) K. Yamazaki and A. Abe: "Loss analysis of IPM motors considering carrier harmonics - Calculation of eddy current loss in permanent magnet using 3D finite element method", IEEJ Trans. IA, Vol.127, No.1, pp.87-94 (2007-1) (in Japanese)

山崎克巳・阿部 敦：「キャリア高調波を考慮した IPM モー夕の損 失解析一三次元有限要素法に上る永久磁石渦電流損算定一」, 電学論 D, 127, 1, pp.87-94 (2005-1)

(7) K. Yamazaki, S. Ohki, A. Nezu, and T. Ikemi: "Development of interior permanent magnet motor reducing harmonic iron losses under field weakening control", IEEJ Trans. IA, Vol.127, No.8, (2007-8) (in Japanese) (in press) 山崎克巳 · 大木俊治・根津章氏 ·池見 健 : 「弱め界磁制御時の高調 波鉄損を低減した IPM モータの開発」,電学論 D, 127, 8 (2007-8) (掲 載決定)

山 崎 克 巳 (正員) 1989 年早稲田大学大学院理工学研究科

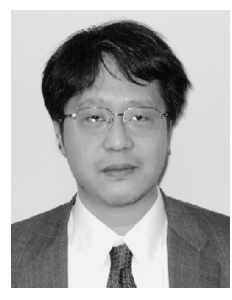
電気工学専攻修士課程修了。同年（株）東芝医用 機器技術研究所。1992 年帝京大学助手。1997 年 千葉工業大学講師, 助教授を経て, 2007 年教授, 現在に至る。回転機の電磁界解析に関する研究に 従事。工博。1996 年電気学会論文発表賞, 2004 年 IEEE CEFC Best Poster Paper Award，2006 年 ICEM Best Poster Paper Award 受賞。

石 上 洋 希 (学生員) 現在, 千葉工業大学大学院電気電子情

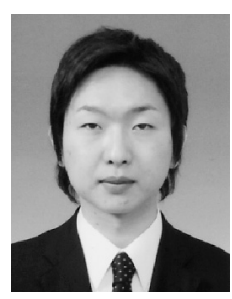
報工学専攻修士課程在学。主として, 形状最適化 計算のための有限要素メッシュ生成法に関する研 究に従事。 